\title{
IKLAN LAYANAN MASYARAKAT DAN RESPON KHALAYAK
}

\author{
Mukaromah $^{1}$, Dzuha Hening Yanuarsari ${ }^{2}$, Mutia Rahmi Pratiwi ${ }^{3}$ \\ Program Studi Ilmu Komunikasi ${ }^{1,3}$, Program Studi Desain Komunikasi Visual ${ }^{2}$ \\ Fakultas Ilmu Komputer, Universitas Dian Nuswantoro Semarang \\ mukaromah@dsn.dinus.ac.id, dzuha.yanuarsari@dsn.dinus.ac.id,mutia.rahmi@dsn.dinus.ac.id
}

\begin{abstract}

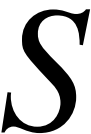
emarang is the capital city of Central Java with high density characteristic and well known as a trading transit place. The Government of Semarang city is actively socializing the government's service programs through various media, one of these is Videotron. There are various kind of social advertisements in Tugumuda Semarang videotron and the research shows that there are 4 social ads that are remembered by the society: Obeying The Traffic Rules, Tax Amnesty, Report to Hendy and Saber Pungli. This research aims to analyze the people's response towards those ads. This research uses quantitative approach, descriptive as the method, and Agenda setting theory.
\end{abstract}

Keyword: Public service advertisement, Agenda Setting, Videotron

\begin{abstract}
ABSTRAK
- emarang adalah salah satu ibukota provinsi di Jawa Tengah Indonesia yang memiliki jumlah kepadatan penduduk yang cukup tinggi dan terkenal sebagai kota transit perdagangan. Pemerintah Kota Semarang saat ini tengah giat melakukan gerakan sosialisasi berbagai layanan kegiatan pemerintahan melalui berbagai media, salah satunya adalah videotron. Iklan Layanan Masyarakat yang disajikan di Videotron Tugumuda Semarang cukup beragam dan berdasarkan hasil penelitian terdapat empat ILM yang cukup diingat oleh masyarakat, yaitu: Tertib Berlalu Lintas, Amnesty Pajak, Lapor Hendy dan Saber Pungli. Penelitian ini bertujuan untuk mengkaji respon masyarakat terhadap empat Iklan Layanan Masyarakat tersebut. Penelitian ini merupakan penelitian kualitatif dengan metode deskriptif dan diulas dengan teori Agenda Setting.
\end{abstract}

Kata Kunci: Iklan Layanan Masyarakat, Agenda Setting, Videotron 


\section{PENDAHULUAN}

Videotron merupakan salah satu media periklanan luar ruang selain Baliho, umbulumbul, spanduk, banner yang banyak ditemui di berbagai titik strategis perkotaan sebagai bagian media periklanan alternatif. Dalam peraturan daerah pemerintah kota Semarang mengenai reklame, videotron masuk dalam istilah Megatron yaitu reklame yang bersifat tetap menggunakan layar monitor besar berupa program reklame atau iklan bersinar maupun tidak dengan gambar dan/atau tulisan berwarna yang dapat berubah-ubah, terprogram dan menggunakan tenaga listrik (Perda Kota Semarang No.14 tahun 2012). Penggunaan istilah videotron digunakan merujuk pada istilah yang sering digunakan oleh masyarakat mengenai penggunaan iklan melalui media ini.

Semarang sebagai salah satu kota metropolitan tak luput dari terpaan menjamurnya videotron di berbagai sudut kota. Tidak kurang dari sepuluh titik videotron terdapat di kota Semarang. Kepemilikan Videotron ini sebagian milik swasta yang disewakan murni untuk kepentingan komersial dan sebagian videotron milik pemerintah yang digunakan untuk layanan informasi kemasyarakatan. Beberapa videotron milik pemerintah kota Semarang diantaranya adalah dua titik videotron yang berada di pusat kota dan dekat dengan identitas kota Semarang Tugumuda. Titik videotron tersebut terletak diatas pos polisi Tugu Muda dan videotron yang terletak di depan gedung Pandanaran yang merupakan salah satu gedung tempat pemerintah kota Semarang melalukan kegiatan pemerintahan kota dalam kesehariannya selain gedung balaikota yang terletak di jalan Pemuda Semarang. Kepemilikan kedua videotron ini adalah milik pemkot Semarang bekerjasama dengan pihak lain yang terkait. Sebagai contoh videotron diatas pos polisi Tugu Muda Semarang, Pemkot Semarang bekerjasama dengan polrestabes Semarang dan yang berada di depan gedung Pandanaran pemkot Semarang bekerja sama dengan Bea Cukai. (http://daerah.sindonews.com/read/1014842/ 151/ diunduh tgl 23 Mei 2017). Tugumuda merupakan salah satu kawasan strategis di Kota Semarang selain kawasan Simpang Lima yang lebih dikenal dengan pusat perdagangan. Daerah Tugu Muda Semarang merupakan suatu kawasan yang berdiri landmark kota, yaitu sebuah Tugu yang berada di tengah taman yang diberi nama "Tugumuda" sebagai penanda tentang keberadaan sejarah pemuda di Kota Semarang dalam mempertahankan kotanya melawan kolonialisme. Selain itu, di kawasan ini juga terdapat bangunan Lawang Sewu sebagai bangunan cagar budaya yang 
juga icon Kota Semarang dan destinasi wisata. Kawasan Tugumuda Semarang juga dikelilingi oleh gedung Pemerintahan Kota, Kawasan pendidikan (sekolah, perpustakaan, dan perguruan tinggi), Museum dan tempat peribadatan sehingga laju lalu lintas dan lalu lalang orang sangat padat Sehingga tidak mengherankan jika kawasan ini banyak dilirik oleh pihak tertentu untuk menyebarkan informasi terkait usaha komersial maupun informasi umum bagi masyarakat karena kestrategisan tempatnya. Maka tidaklah mengherankan apabila kestrategisan tersebut juga membuat Pemkot Semarang perlu mengatur pemasangan alat promosi (reklame) dalam Perda Kota tentang Penyelenggaraan Reklame nomor 8 tahun 2006 agar Semarang tidak banjiri oleh papan reklame yang merusak keindahan tata kota (http://www.radarsemarang.com/20160322/h $\underline{\text { utan-reklame-simpang-lima }}$

Pemerintah memiliki kewajiban untuk memberikan pelayanan kepada masyarakatnya sesuai dengan undangundang no. 23 tahun 2014 tentang pemerintah daerah. Demikian halnya dengan pemerintah kota Semarang dengan total penduduk hampir mencapai dua juta jiwa memerlukan sarana media penyalur informasi publik guna membina hubungan dengan para pemangku kepentingan termasuk masyarakat sebagai stakeholdersnya. Salah satunya adalah pembuatan dan penyebaran iklan layanan yang ditampilkan melalui media videotron.

Terdapat beberapa iklan layanan masyarakat yang tampil di videotron kawasan Tugumuda Semarang, diantaranya: iklan informasi tertib berlalu lintas, iklan penerimaan anggota Polri, iklan penerimaan taruna Akpol, iklan safety riding, iklan cukai rokok, iklan visit Jateng, iklan informasi gedung pelayanan publik Pemkot Semarang.

Optimalisasi publikasi dan manajemen pemerintahan Kota Semarang ini berbasis pada teknologi, informasi dan komunikasi (TIK) yang dilakukan untuk mendukung pengembangan $e$-government melalui slogan: BE SMARTCITY yang merupakan kepanjangan dari (Based on $\boldsymbol{E}$ government, Semarang

\section{More Accountable, Realistic}

and the Transparent $\boldsymbol{C I T Y}$ ). Hal ini sebagai bentuk perwujudan keterbukaan informasi publik yang dilakukan Pemerintah Kota Semarang.

Iklan layanan masyarakat digunakan untuk menyampaikan informasi, mempersuasi khalayak untuk orientasi fungsi sosial bukan semata orientasi ekonomi seperti layaknya iklan komersial. Keuntungan sosial yang dimaksud adalah munculnya pengetahuan, kesadaran sikap, perubahan perilaku masyarakat terhadap 
masalah atau informasi yang diiklankan. Selain itu tujuan dari iklan layanan masyarakat adalah untuk mendapatkan citra baik atas lembaga yang memasang iklan dari masyarakat atau stakeholders yang mendengarnya (Widyatama, 2009: 104).

\section{METODE}

Penelitian ini dilakukan dengan pendekatan kualitatif untuk mendeskripsikan temuan Pengumpulan data dilakukan melalui indept interview dengan beberapa narasumber pemangku kepentingan.

Metode pengumpulan data dilakukan dengan mengumpulkan data primer dan data sekunder. Data Primer diraih dengan:

1. Penyebaran kuesioner terhadap responden sebanyak 120 (dengan kualifikasi: pernah melintas dan melihat iklan layanan masyarakat (ILM) di kedua videotron Tugumuda Semarang dan berusia 18 tahun keatas).

2. Wawancara dan observasi di lapangan secara langsung dengan narasumber atau informan yang kompeten.

Data sekunder diraih dengan mengamati, membaca maupun mendengar dari fenomena yang ada di lingkungan seperti kepustakaan, dan hasil dokumentasi yang mendukung.
Proses analisis data kualitatif yang harus dilakukan, sebagai berikut (Denscombe, 2007: 297-312):

1. Open coding, yang dilakukan selama mengumpulkan data. Tahap ini mencakup memberi nama, mengkategorisasikan fenomena yang diteliti melalui proses penelaahan yang teliti dengan tujuan untuk mengkategorisasikan fenomena yang diteliti. Hasilnya adalah didapatkannya kategori-kategori umum yang dapat diuraikan berdasarkan ciri-cirinya (property), dimensi kebesarannya (dimension), faktor yang mempengaruhi (supportive) dan contoh nyatanya (example).

2. Axial coding. Tahap ini untuk melihat keterkaitan kategori-kategori yang dihasilkan melalui open coding. Terdapat beberapa kondisi yang dapat digunakan untuk melihat keterkaitan, diantaranya: penyebab dan konsekuensinya, kondisi dan interaksi, strategi dan proses, dan melihat kategori atau konsep pada fenomena tertentu.

3. Selective coding merupakan mengidentifikasi tema besar dalam rencana penelitian dengan melibatkan mengamati data dengan teliti dan berhubungan dengan data sebelumnya. Peneliti melihat secara selektif untuk 
kasus yang menggambarkan tema dan membuat perbandingan dan hal ini dilakukan setelah pengumpulan data lengkap.

\section{PEMBAHASAN}

\section{Teori Agenda Setting}

Penyebaran informasi publik melalui iklan layanan masyarakat dengan menggunakan media Videotron akan digali dengan menggunakan pendekatan teori Agenda Setting. Teori Agenda setting biasanya banyak digunakan pada pemberitaan yang termuat di media massa seperti koran maupun televisi. Teori ini dikemukakan oleh Mc.Combs dan D.L Show . K yang mengemukakan bahwa media mempunyai kemampuan mentransfer isu atau tema untuk mempengaruhi agenda publik. Khalayak akan menganggap suatu hal menjadi penting karena media mengangkat hal tersebut (Griffin, 2003: 490).

Penelitian agenda setting biasanya berfokus pada level objek dan telah mengukur bagaimana media dapat mempengaruhi prioritas yang akan disampaikan kepada objek (isu, kandidat, peristiwa dan masalah). Media mencoba mengatakan apa yang terfikirkan dan memberitahukan bagaimana khalayak memikirkan objek tertentu. Media memberitahukan kepada khalayak karakteristik objek mana yang penting dan mana yang tidak. Agenda setting memiliki beberapa kekuatan, yaitu:

- Berfokus pada interaksi khalayak dengan media.

- Secara empiris membuktikan hubugan antar media. Motivasi khalayak untuk mencari panduan, dan persepsi khalayak terhadap isu media.

- Menggabungkan sejumlah ide yang mirip, termasuk priming, penempatan berita dan kekuatan kisah (Turner, 2010: 350-351).

Fungsi agenda setting mencakup tiga bagian, yaitu: (1) prioritas isu-isu yang akan dibahas media (agenda media), harus diatur; (2) agenda media mempengaruhi atau berinteraksi dengan apa yang masyarakat pikirkan guna menciptakan agenda publik; (3) agenda masyarakat mempengaruhi atau berinteraksi dengan apa yang para pembuat kebijakan dianggap penting disebut agenda kebijakan. Secara sederhana, agenda media mempengaruhi agenda masyarakat dan agenda masyarakat mempengaruhi agenda kebijakan. Agenda media ditentukan oleh beberapa kombinasi pemrograman internal, keputusan manajerial dan editorial. Selain itu juga dipengaruhi oleh faktor eksternal dari sumber-non media (seperti: individu yang 
Iklan Layanan Masyarakat... hal. 219 - 235

berpengaruh secara sosial, pejabat pemerintah, dukungan iklan, dan sebagainya.

\section{AGENDA KEBIJAKAN DARI PIHAK PEMERINTAH}

Peneliti melakukan wawancara dengan beberapa pihak selaku pemangku kepentingan pada iklan videotron di kawasan Tugumuda, yaitu: Kepala Dinas Perindustrian dan Perdagangan Kota Semarang (Ibu Nurjannah) serta Kepala Bagian pengelolaan TIK Dinas Komunikasi dan Informatika Kota Semarang (Bp.Taufan Yudha).

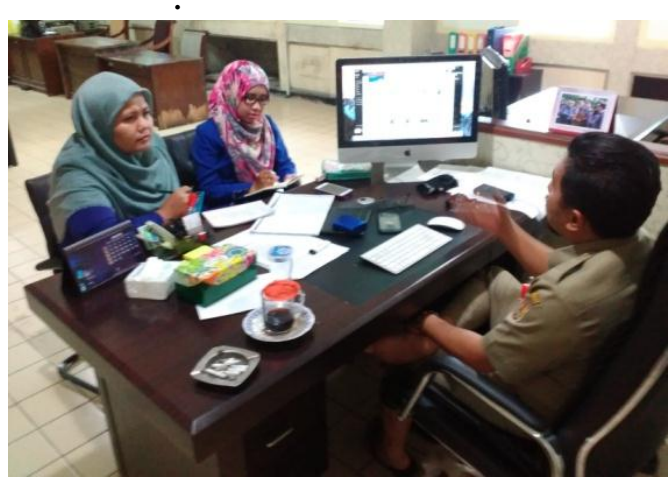

Wawancara dengan Kepala Dinas Perindustrian dan Perdagangan Kota Semarang Sumber: Dokumentasi Peneliti

Peraturan Daerah Kota Semarang Nomor 14 Tahun 2012 menyebutkan, reklame Megatron dan reklame dengan Sinar Laser adalah reklame yang bersifat tetap menggunakan layar monitor besar berupa program reklame atau iklan bersinar maupun tidak dengan gambar dan/atau tulisan berwarna yang dapat berubah-ubah, terprogram dan menggunakan tenaga listrik, termasuk didalamnya vidiotron dan elektronik display (http://dtkp.semarangkota. go.id/, diakses pada tanggal 07 Mei 2017).

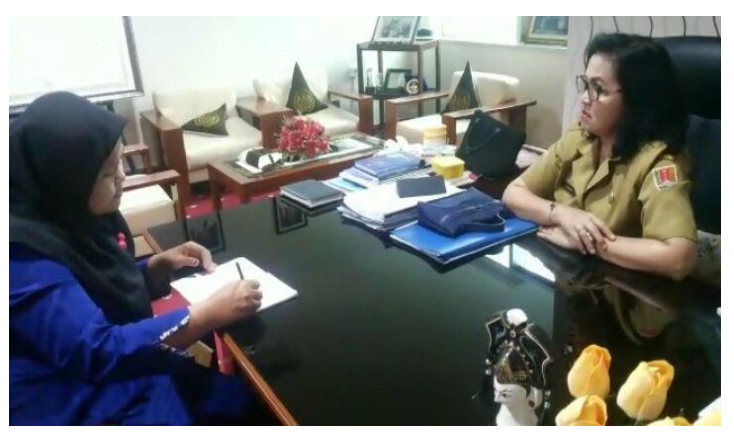

Wawancara dengan Kepala TIK Diskominfo Kota Semarang Sumber: Dokumentasi Peneliti

Hasil wawancara menunjukan bahwa terdapat lima titik videotron yang digunakan untuk sosialisasi Pemerintah Kota Semarang pada tahun 2017, yaitu: videotron yang terletak di depan gedung Pandanaran (milik dinas kementrian dan perdagangan); Videotron di taman Srigunting kawasan Kota Lama; Videotron dekat SMP 2 Semarang; Daerah kalibanteng; dan Halaman balaikota. Penelitian ini fokus mengkaji pada pesanpesan ILM yang ditayangkan di Videotron depan Gedung Pandanaran. Secara kepemilikan, videotron di depan gedung Pandanaran merupakan milik Pemerintah 
Kota Semarang namun berada dibawah wewenang Dinas Perindustrian dan Perdagangan (Disperindag) Kota Semarang.

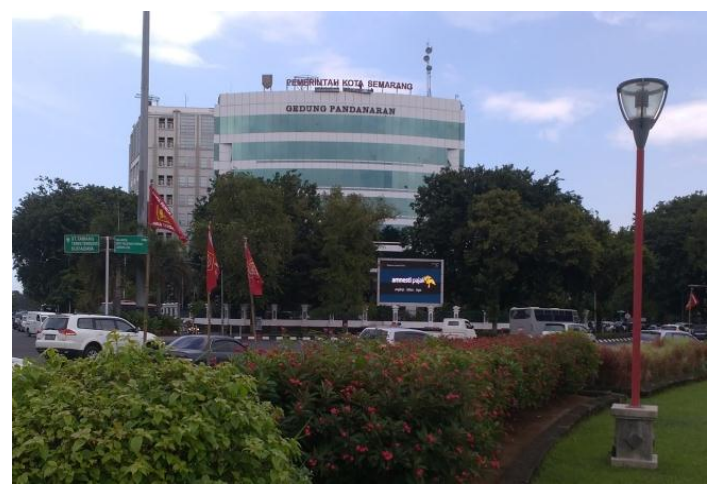

Videotron tersebut sudah berdiri sejak tahun 2014 yang merupakan hibah dari Kementrian Perindustrian dan Perdagangan.

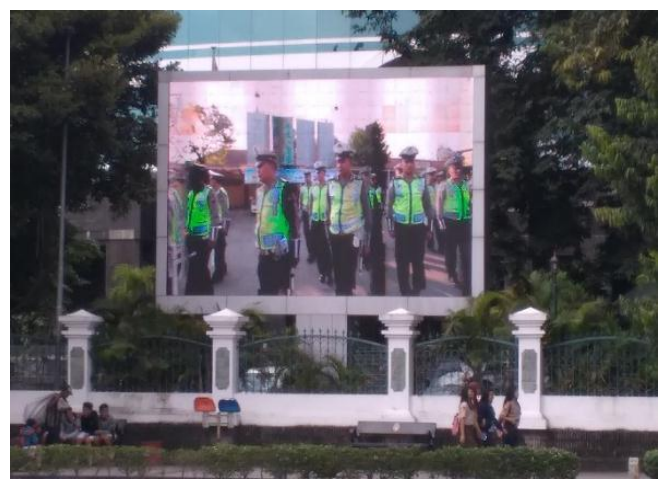

\section{Videotron di depan Gedung Pandanaran Kawasan Tugumuda Sumber : Dokumentasi peneliti}

Iklan merupakan segala bentuk penyajian dan promosi secara nonpribadi dari ide barang dan pelayanan yang dibayar oleh sponsor tertentu. Dengan adanya iklan, penjual menyampaikan berita kepada konsumen melalui media surat kabar, majalah, surat langsung atau melalui media lainnya. Dalam UU No.32 tahun 2002 tentang penyiaran bab I pasal 1 (5) disebutkan bahwa siaran iklan adalah siaran informasi yang bersifat komersial dan layanan masyarakat tentang tersedianya jasa, barang, dan gagasan yang dapat dimanfaatkan oleh khalayak dengan atau tanpa imbalan kepada lembaga penyiaran yang bersangkutan (Mustafa,1996). Periklanan sebagai salah satu bentuk dari komunikasi impersonal (impersonal communication) yang digunakan perusahan barang atau jasa (Lupiyoadi, 2006).

Iklan layanan masyarakat merupakan iklan yang digunakan untuk menyampaikan informasi, mempersuasi khalayak untuk orientasi fungsi sosial bukan semata orientasi ekonomi seperti layaknya iklan komersial. Keuntungan sosial yang dimaksud adalah munculnya pengetahuan, kesadaran sikap, perubahan perilaku masyarakat terhadap masalah atau informasi yang diiklankan. Tujuan dari iklan layanan masyarakat adalah untuk mendapatkan citra baik atas lembaga yang memasang iklan dari masyarakat atau stakeholders yang mendengarnya (Widyatama,2009:104). 
Iklan Layanan Masyarakat... hal. 219 - 235

Iklan Layanan Masyarakat yang ditampilkan di videotron depan Gedung Pandanaran cukup beragam, seperti yang disampaikan oleh Kepala Bagian pengelolaan TIK Dinas Komunikasi dan Informatika Kota Semarang (Bp.Taufan Yudha): "Informasi umum kota atau yang berkaitan dengan event tahunan/ temporary Kota Semarang seperti iklan lapor hendi, saber pungli, Laporan APBD, event-event kota Semarang”. Hal ini selaras dengan yang disampaikan oleh ibu Nurjannah selaku Kepala Bagian Disperindag:

“Jenis ILM yang pernah tampil videotron antara lain Iklan cukai rokok; Event kota seperti pameran produk UMKM; Laporan kegiatan pemerintah kota seperti: laporan neraca keuangan; Ucapan selamat Datang untuk kunjungan tamu tamu kota Semarang; Informasi sarana prasarana; Informasi yang berkaitan dengan masyarakat (bahaya dan penanganan demam berdarah, kehamilan, dsb)"

Pihak pengelola dari Diskominfo dan Disperindag menyampaikan secara tegas bahwa aturan iklan yang layak tayang di vediotron depan gedung Pandanaran kawasan Tugumuda Semarang adalah hanya
Iklan Layanan Masyarakat (ILM) dengan tidak memperbolehkan menampilkan iklan komersial termasuk logo atau corporate indentity sekalipun. Termasuk iklan layanan masyarakat disini antara lain menampilkan kegiatan-kegiatan sosial, informasi layanan publik, informasi saluran/telpon aduan bagi masyarakat dll. Disperindag selaku penanggung jawab videotron di depan Gedung Pandanaran Semarang menegaskan pula bahwa gambar visual yang tayang akan selalu dipantau dan diperhatikan apakah cukup efektif untuk ditayangkan atau tidak.

Iklan yang akan tayang di Videotronpun harus melalui serangkaian proses yang tidak mudah. Pihak Diskominfo menyampaikan bahwa mekanisme penayangan iklan adalah "Rapat koordinasi dengan pihak pemangku (pihak terkait, kepala dinas perindustrian dan perdagangan kota semarang); Mengajukan Permohonan dan persetujuan dari bagian terkait; Materi iklan tidak mengandung muatan komersial; Setelah selesai masa penayangan membuat laporan pertanggungjawaban”. Selain itu, di tingkat internal diskominfo naskah dari iklan yang akan tayang melalui beberapa langkah, yaitu: "Kepala TIK berkoordinasi dgn
dinas terkait tentang iklan yg akan
dipublikasi, kemudian di-
komunikasikan dengan mitra 
bagian kreatif diskominfo), mitra mengolah dengan konsep bahasa visual dan bahasa iklan, dikoreksi oleh kepala TIK Diskominfo Kota Semarang, setelah itu disampaikan ke dinas pemesan (terkait pesan iklan), mendapat persetujuan dari pemangku terkait, baru dilanjutkan dengan publikasi ke videotron atau media sosial yang sesuai.

Pihak Disperindag menambahkan bahwa "Seleksi iklan yang akan dimunculkan di videotron ada pada masing masing SKPD (Satuan Kerja Perangkat Daerah) yang telah di rapatkan oleh pihak terkait”. Kepala Bagian pengelolaan TIK Dinas Komunikasi dan Informatika Kota Semarang (Bp.Taufan Yudha) menyatakan bahwa:

"Dalam pengelolaan naskah iklan layanan masyarakat, jumlah Tim Internal Bagian TIK Diskominfo terdiri tim kreatif dan grafis yang berjumlah 4 orang (ASN dan Non ASN). Non ASN adalah mitra (bagian video grafis, desain, editor dan music director)"

\section{Deskripsi Iklan Layanan Masyarakat "Tertib Berlalu Lintas" dari Kepolisian}

Untuk waktu pengerjaan Iklan Layanan Masyarakat sendiri sifatnya kondisional. Ketika sangat urgent untuk segera dipublikasikan maka paling cepat waktu pengerjaan adalah satu hari.

\section{Iklan Layanan Masyarakat yang Mendapatkan Perhatian Besar dari Khalayak}

Berdasarkan olah data terhadap 120 responden yang pernah melintas di kawasan Tugumuda Semarang dan di Tanya tentang Iklan Layanan Masyarakat yang paling diingat saat melihat ILM di videotron Depan Gedung Pandanaran di kawasan Tugumuda terdapat 4 iklan layanan masyarakat yang paling diingat oleh responden pada bulan Februari 2017 yaitu iklan tentang tertib berlalu lintas sebanyak 80 orang atau 66,67 $\%$ disusul kemudian dengan iklan tentang amnesty pajak dari Dirjen Pajak sebesar $50,83 \%$, iklan Lapor Hendi dari Pemkot Semarang sebesar 40,83\% dan iklan tentang Saber Pungli sebesar 30,83\%.

Berikut ini deskripsi singkat mengenai iklan layanan masyarakat yang diingat tersebut:

Iklan ini memiliki gambar dan teks berbahasa Inggris. Iklan Tertib Lalu Lintas ini merupakan iklan layanan masyarakat 
yang dibuat oleh pihak Kepolisian Kota Semarang dan Pemerintah Kota Semarang dengan durasi 3 menit 56 detik. Iklan ini diawali dengan gambar apel pagi yang dilakukan oleh anggota kepolisian (ditunjukan dengan banyaknya peserta yang hadir). Menceritakan tentang seorang anggota polisi yang sedang berdiri di depan pos dan menyetop ibu-ibu saat sedang menggoncengkan kedua anaknya, 1 anak pun hanya diam melihat ibu itu pergi. laki-laki duduk di depan dan 1 anak perempuan duduk membonceng di belakang. Kedua anak ibu ini masih duduk di bangku SD dilihat dari seragam yang digunakan. Polisi mencegat ibu ini karena anaknya tidak menggunakan helm namun justru si ibu menunjukan rasa marah sembari mengomel (dilihat dari mimik muka dan bahasa tubuh) dan kemudian beranjak pergi dengan motornya. Polisi
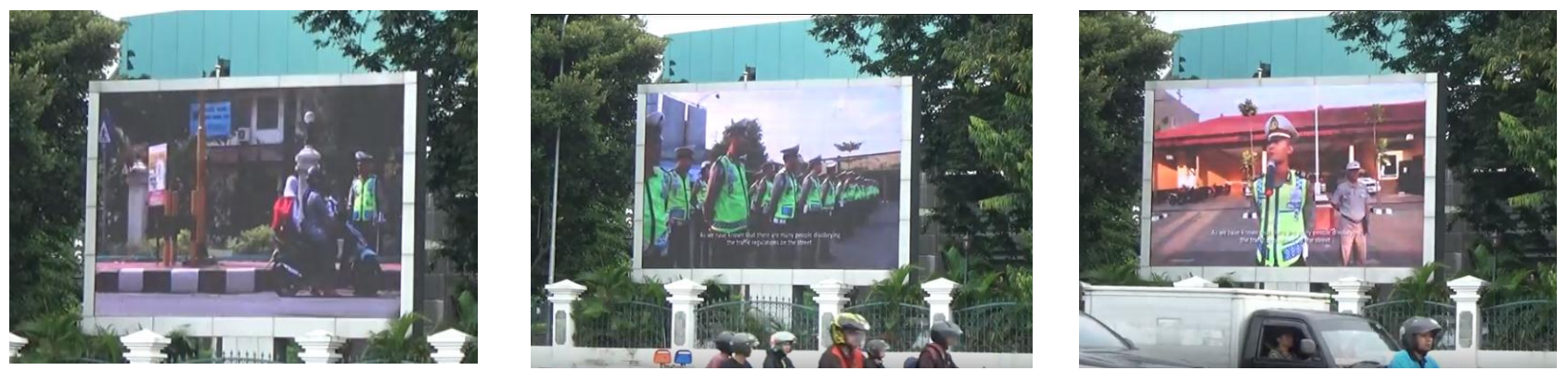

Pict.1: Scene awal iklan "Taat Lalu Lintas"

Sumber: Dokumentasi Peneliti

Pada scene berikutnya menceritakan bahwa Polisi sudah tiba di rumah dan langsung berbincang dengan istrinya. Mereka pun terlihat sedang mengobrol. Pada scene berikutnya terlihat seorang laki-laki berkemeja batik sedang menunggu seseorang di depan rumah sembari menunggu istri dan anaknya siap untuk pergi bersama. Sebelum bepergian, si anak sempat bertanya kepada bapaknya dan si bapak menasehati anak tersebut. Setelah itu mereka pergi bersama dengan naik motor dimana bapak dan ibu menggunakan helm namun si anak yang duduk di depan tidak menggunakan helm dan hanya menggunakan kerudung. Merekapun melakukan perjalanan namun sayang dari arah yang berlawanan muncul mobil dan motor yang melaju cukup kencang sehingga kecelakaan pun terjadi. Bapak dan ibu luka-luka dan masih sadarkan diir karena kepala mereka aman terlindungi oleh helm. Namun sayang anak mereka meninggal di 
tempat hal ini terlihat dari ibu dan ayah yang menggendong anak mereka sambil menangis meratap.
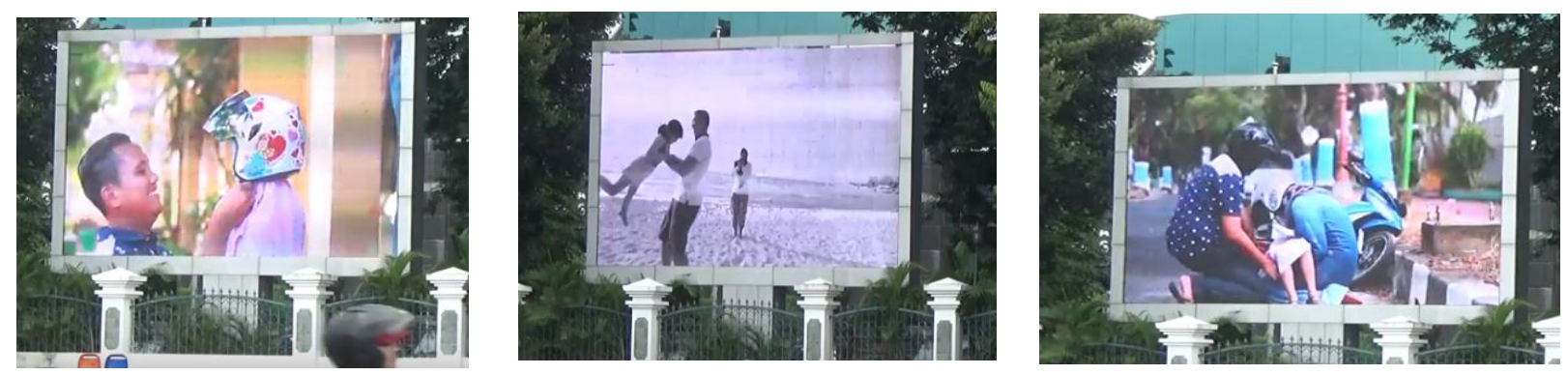

Pict.2: Alur Scene Di Dalam Iklan "Taat Lalu Lintas”

\section{Sumber: Dokumentasi Peneliti}

Scene berikutnya ditunjukan dengan warna sephia yang menunjukan mengingat kembali masa lampau. Scene ini menceritakan saat bapak ibu dan anak sedang asyik bermain di pantai. Kemudian di scene berikutnya menceritakan bahwa apa yang dipikirkan hanyalah bayangan (imajinasi buruk dari pikiran seorang ayah) bapak ini ternyata sedang membayangkan apabila anaknya tidak menggunakan helm maka akan terjadi kecelakaan yang dapat berujung pada kematian. Kemudian si bapak mengambilkan helm untuk anaknya dan memakaikannya untuk menghindari hal yang tidak diinginkan. Setelah itu si bapak memeluk erat anak perempuannya sambil tersenyum kepada istrinya. Scene berikutnya menceritakan saat si bapak menggunakan seragam polisi melihat anaknya dengan bangga karena sudah lulus kuliah (ditunjukan dengan menggunakan toga dan pakaian wisuda) dengan latar lokasi salah satu sudut Gedung Universitas.

\section{Deskripsi Iklan Layanan Masyarakat “Amnesty Pajak" dari Dirjen Pajak}

Iklan layanan masyarakat tentang "Amnesty Pajak" adalah iklan yang dikeluarkan oleh direktorat dirjen pajak (pemerintah) yang diberikan kepada pembayar pajak (wajib pajak) tentang pengampunan pajak dalam skala nasional untuk memberi kesempatan kepada wajib pajak untuk diberikan pengampunan 
pembayaran pajak dengan syarat tertentu. Kampanye tentang "Amnesty Pajak" ini dilakukan melalui beberapa lini pada rentang tahun 2016-2017. Iklan ini muncul dalam bentuk infografis audio visual sebagai bagian kampanye sosial. Iklan ini diawali dengan logo amnesty pajak yang bergambar merpati emas dilanjutkan dengan slide gambar alasan mengapa ada kebijakan tax amnesty oleh Negara.

Latar belakang kebijakan tax amnesty ini muncul karena adanya kebutuhan dana untuk pembangunan, sementara ada sebagian dana WNI yang banyak parkir di luar negeri. Indonesia memasuki era keterbukaan informasi, termasuk Automatic Exchange of Information sehingga dengan adanya ini tidak mungkin wajib pajak bisa menghindar dari kewajiban membayar pajak. Latar belakang yang lain munculnya kebijakan amnesty pajak adalah kepatuhan perpajakan secara keseluruhan masih rendah. Selain latar belakang munculnya kebijakan amnesty pajak ini, dalam iklan tersebut juga disampaikan tujuan dan manfaat adanya amnesty pajak baik bagi Negara maupun warganegara dan wajib pajak. Adanya target pencapaian pajak sebesar $1.539 \mathrm{~T}$ juga menjadi tujuan dikelurakannya kebijakan amnesty pajak. Iklan ini di tutup dengan ajakan untuk memanfaatkan momentum kebijakan pengampunan ini dengan tagline Ungkap-Tebus-Lega.
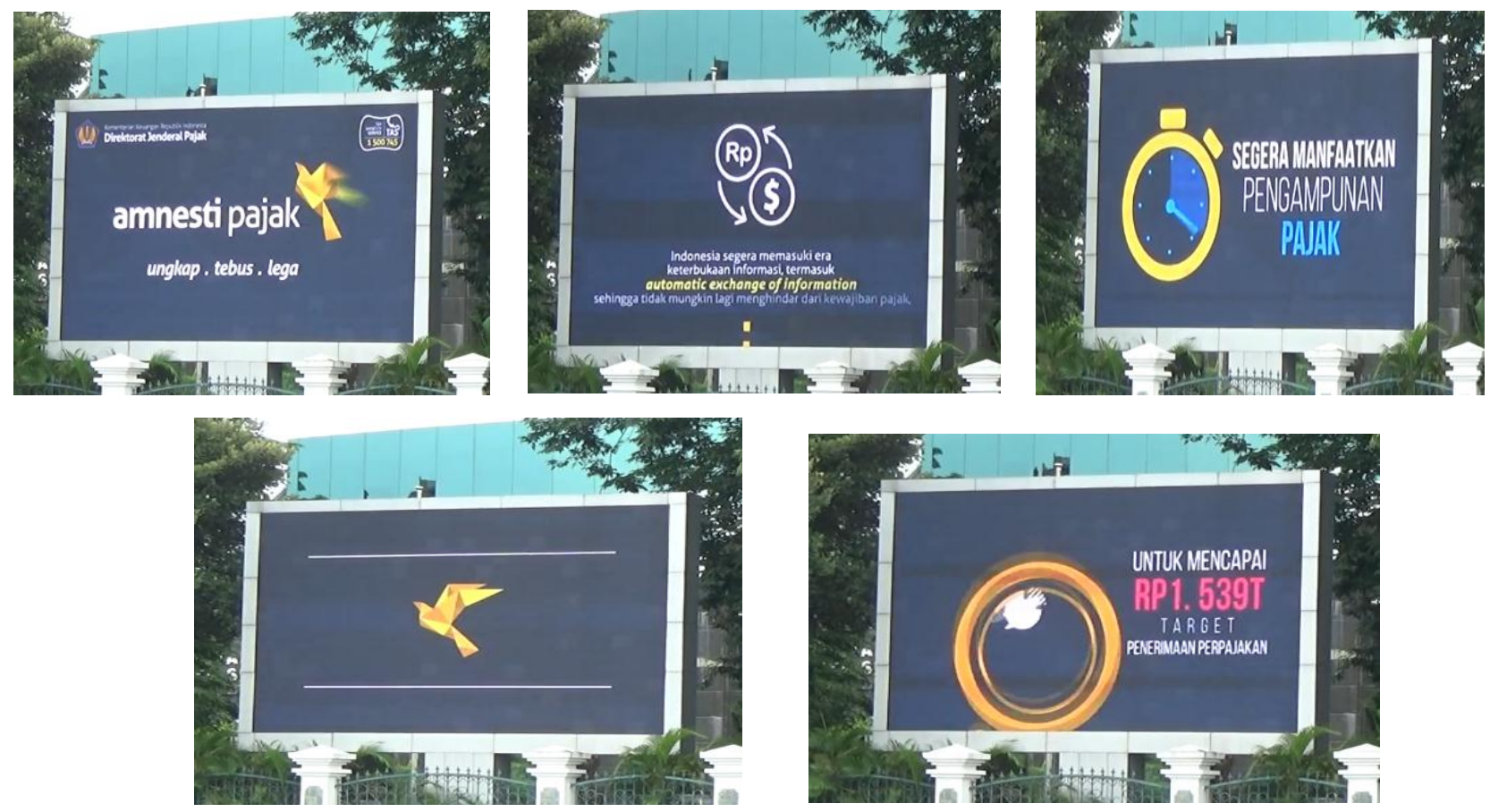

Pict.3: Alur Scene Di Dalam Iklan “Amnesty Pajak"

Sumber: Dokumentasi Peneliti 
Deskripsi Iklan Layanan Masyarakat "Lapor Hendi” dari Pemerintah Kota

\section{Semarang}

Iklan ini merupakan iklan layanan masyarakat dari PemKot Semarang dengan durasi 12 detik. Iklan ini merupakan iklan indografis yang menginformasikan adanya layanan "Lapor Hendi" berikut dengan nomor sms, twitter dan website. Latar iklan ini diberi warna putih dengan dominasi design tulisan merah dan hitam untuk memperjelas tulisan yang ditekankan. Iklan ini untuk menginformasikan kepada masyarakat kota Semarang bahwa ada saluran langsung tanpa melalui birokrasi yang rumit untuk menyampaikan keluhan atau uneg uneg mengenai pelayanan pemerintah Kota Semarang kepada Walikota langsung dalam hal ini walikota incumbent yaitu Hendi Hedrardi.
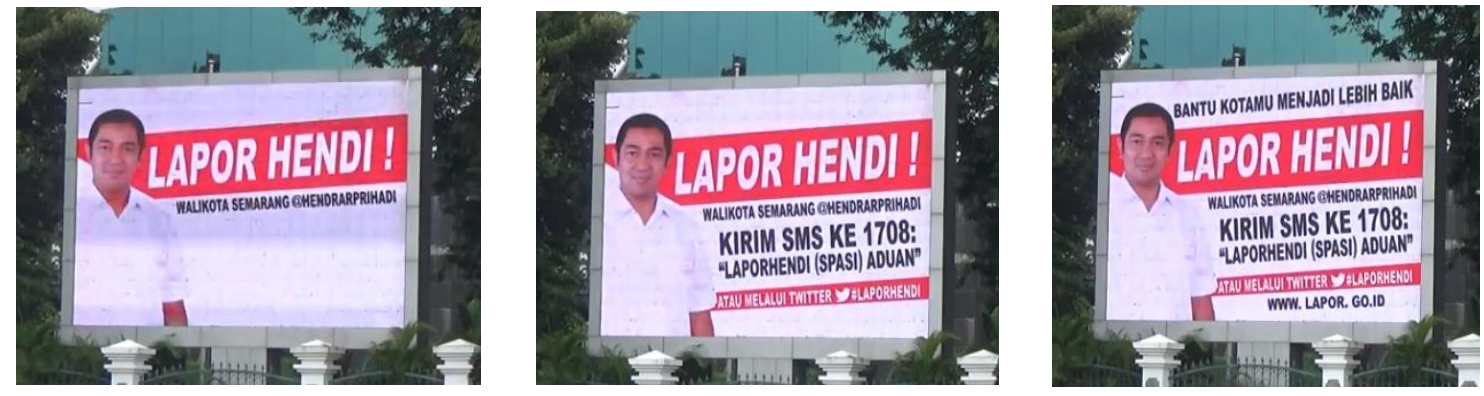

Pict.3: Alur Scene Di Dalam Iklan "Lapor Hendi"

Sumber: Dokumentasi Peneliti

Pungli. Scene kedua berisi tulisan Perpres

Deskripsi Iklan Layanan Masyarakat

"Saber Pungli" dari Pemerintah Kota

\section{Semarang}

Iklan ini merupakan iklan layanan masyarakat yang dikeluarkan oleh Pemerintah Kota Semarang dengan tema "Saber Pungli" yang berdurasi 1 menit. Tampilan iklan dalam infografis yang dibagi ke dalam beberapa scene. Scene pertama berisi gambar dan logo Pemerintah Kota Semarang serta tulisan dan logo Saber
No. 87 Tahun 2017; You Can Stop Corruption; Satgas: Sapu Bersih Pungutan Liar. Scene ketiga berisi gambar tangan yang sedang memberikan pungli ke tangan orang lain dan tulisan "Stop Pungli Tim Saber Pungli Siap Beraksi”. Scene keempat berisi gambar pihak-pihak yang menjadi tim saber pungli Kota Semarang. Scene kelima berisi tulisan nomor telephone dan email yang bisa dihubungi ketika masyarakat menemukan pungli di sekitar mereka. Scene keenam 
berisi gambar Walikota Semarang dan tulisan ajakan "Mari Bersama Wujudkan Indonesia Bebas Pungli”. Scene ketujuh berisi gambar pihak-pihak yang menjadi Tim
Satgas Pungli Kota Semarang. Diakhir scene ditunjukan bahwa iklan layanan masyarakat ini disampaikan oleh "Tim Satgas Saber Pungli Kota Semarang”.
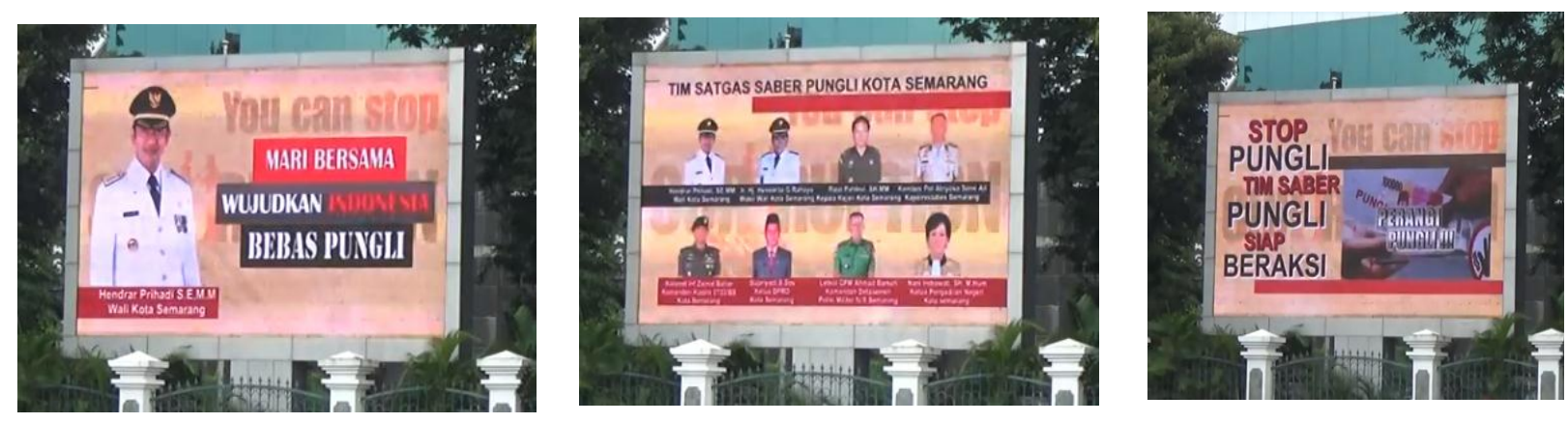

\section{Pict.4: Alur Scene Di Dalam Iklan "Saber Pungli”}

Sumber: Dokumentasi Peneliti

Agenda Publik: Respon Masyarakat

\section{Terhadap Iklan Layanan Masyarakat} (ILM)

Makna merupakan pemahaman pesan. Pesan mencakup simbol-simbol verbal dan non verbal, tanda dan perilaku. Orang-orang mengharapkan dapat menghasilkan makna umum melalui pesan yang disampaikan. Seseorang memiliki berbagai pengetahuan mengenai hal tertentu namun sangat bervariasi dalam kemampuan mereka untuk menyampaikan makna bersama. Memahami makna pesan orang lain akan terjadi apabila dua komunikator dapat menimbulkan makna umum dari kata-kata dan kode-kode nonverbal. Ketika seseorang menggunakan bahasa, makna menfasilitasi respon yang tepat sehingga menunjukan bahwa pesan tersebut dipahami (Pearson dan Nelson, 2011: 11).

Demikian juga dengan penggunaan pesan yang ditampilkan dalam iklan layanan masyarakat di kawasan Tugumuda Semarang. Baik Pesan secara tersurat dan tersirat yang coba disosialisasikan oleh pemangku kepentingan (dalam hal ini pemerintah daerah Kota Semarang dan satuan terkaitnya) kepada masyarakat selaku stakeholders pemerintah kota. Masyarakat disini bertindak sebagai khalayak yang menerima paparan pesan yang tersaji di media sebagai bagian dari penjabaran 
agenda kebijakan yang dibuat oleh pemerintah daerah Kota Semarang.

Menurut Nightingale (2003), terdapat empat jenis khalayak, yaitu:

- Audience as "the people assembled" (penonton) merupakan kumpulan khalayak yang diukur ketika memberikan perhatian pada tampilan media atau produk tertentu pada waktu yang ditentukan.

- Audience as "the people addresed" (khalayak yang "terlibat") merupakan kelompok yang dibayangkan oleh komunikator dan untuk siapa konten dibuat.

- Audience as "happening" pengalaman penerimaan individu secara personal atau dengan orang lain merupakan peristiwa interaktif dalam kehidupan sehari-hari, berlangsung dalam konteks tempat dan features lainnya.

- Audience as "hearing” or "audition" merujuk pada pengalaman khalayak yang berpartisipasi, ketika audiens turut terlibat dalam sebuah pertunjukan atau diperbolehkan untuk berpartisipasi melalui alat untuk memberikan respon di saat yang bersamaan (McQuail, 2010: 398399).

Dalam penelitian ini, audiens atau khalayak merupakan jenis khalayak sebagai penonton dan sebagai khalayak yang terlibat. Termasuk jenis khalayak sebagai penonton karena dalam hasil penelitian audiens tidak menyatakan memiliki pengalaman berkaitan dengan iklan tersebut dan tidak terlibat langsung dalam konten yang dibuat. Dalam penelitian ini, masyarakat juga termasuk sebagai khalayak yang terlibat karena berdasarkan hasil wawancara dengan pemangku kepentingan saat membuat agenda iklan apa yang akan disampaikan mereka (komunikator/ creator) memikirkan siapa khalayak yang mau dituju berikut pilihan bahasa yang digunakan dan pengadeganan tampilan iklan. Selain itu, masyarakat juga merupakan kelompok yang dibayangkan oleh komunikator dan untuk siapa konten dibuat.

Respon yang disampaikan oleh responden terhadap iklan layanan masyarakat yang tayang di videotron didominasi oleh tanggapan yang positif walaupun tanggapan yang negatif dari responden tetap ditemukan dalam proses penelitian. Beberapa alasan dari responden yang menyatakan pesan ILM yang ditayangkan positif adalah:

Islamic Comunication Journal Volume 02, Nomor 02, Juli-Desember 2017 
1. Pesannya dianggap penting untuk warga

2. Gambarnya cukup jelas

3. Terdapat penekanan pesan di bagian akhir iklan

4. Ketepatan pemilihan lokasi dimana Tugumuda merupakan kawasan strategis dan pusat kota, landmark kota semarang.

5. Iklan muncul sebagai pengisi waktu luang sembari menunggu lampu lalu lintas

6. Bahasa iklannya sederhana dan mudah dipahami.

Adapun tanggapan beberapa responden menyatakan bahwa pesan ILM yang ditayangkan memiliki beberapa kelemahan (menunjukan sisi negatif), diantaranya:

1. Beberapa iklan terlalu panjang sehingga iklan belum selesai putar, lampu lalu lintas sudah berganti

2. Pesan iklan terhalang oleh tanaman/ pohon jalan yang rimbun belum terpangkas

3. Audio nya kurang jelas sehingga pesan audio kurang dimengerti oleh pengendara

4. Font untuk subtile iklan tertlalu kecil sehingga terkadang dari jarak pandang pengendara tidak terlihat jelas

5. Bahasa yang ditunjukan di beberapa hal dianggap bertele-tele

\section{PENUTUP}

Videotron Tugumuda Semarang merupakan salah satu videotron di kota Semarang yang hanya menampilkan Iklan Layanan Masyarakat tanpa adanya unsur iklan layanan komersial. Berdasarkan hasil penelitian, terdapat empat iklan layanan masyarakat yang mendapat perhatian cukup tinggi dari masyarakat, yaitu: iklan Tertib Berlalu Lintas, Amnesty Pajak, Lapor Hendy dan Saber Pungli. Dalam teori agenda setting terhadap tiga poin yang penting yaitu mengenai agenda media, agenda masyarakat dan agenda kebijakan. Agenda media dan agenda kebijakan dalam pembuatan iklan layanan masyarakat ini merupakan dua hal yang tak terpisahkan. Hal ini dikarenakan videotron yang ada di depan gedung Pandanaran berada dibawah tanggung Pemerintah Kota Semarang yang didalamnya menaungi Disperindag (Dinas Perdagangan dan Perindustrian). Pengampu kebijakan mengenai konten media adalah Disperindag (Dinas Perdagangan dan Perindustrian) dan menggandeng Diskominfo untuk memproduksi iklan yang akan ditayangkan. Agenda publik dilihat dari bagaimana 
masyarakat merespon iklan layanan masyarakat yang tampil di videotron dimana hasil menunjukan bahwa dari 120 responden, dominasi respon yang diberikan adalah positif. Dan masyarakat bertindak sebagai penonton dan pihak yang terlibat karena selama mengambil kebijakan para pemangku kepentingan juga mempertimbangkan masalah-masalah di masyarakat berkaitan dengan pelayanan publik dan efektivitas iklan yang akan ditayangkan (durasi, desain, dan sebagainya).

\section{DAFTAR PUSTAKA}

Denscombe, Marty. (2007). The Good Research Guide: For Small Scale Social Research Project (3rd ed.). England : McGraw-Hill.

Griffin, EM. (2003). A First Look At Communication Theory. NewYork: McGrawHill

McQuail, Denis. (2010). Mass Communication Theory (6th ed). California : Sage Publication, Inc.

Pearson, Judy C., Paul E. Nelson, Scott Titsworth dan Lynn Harter. (2011). Human Communication (4 ed.). England: McGraw-Hill.

Richard West dan H. Turner, Lynn. (2010). Introducing Communication Theory : Analysis and Application. Jakarta : Salemba Humanika

Widyatama, Rendra. (2009). Pengantar Periklanan. Jakarta: Pustaka Book http://daerah.sindonews.com/read/1014842/ 151/ diunduh tgl 23 Mei 2017 http://dtkp.semarangkota.go.id/, diakses pada tanggal 07 Mei 2017

http://www.radarsemarang.com/20160322/h utan-reklame-simpang-lima, diakses pada tanggal 06 Maret 2017

\section{Internet}

